\title{
THE DUTY PROBLEM IN NEGLIGENCE CASES: II
}

\author{
The Moral, Economic, Preventive and Justice Factors
}

In the part of this paper published in an earlier number of the $R_{E-}$ viEw, ${ }^{1}$ I sought to develop the idea that legal "duties" are determined by factors outside any legal theory which has yet crystallized. These factors were designated: (1) The administrative factor; (2) the moral or ethical factor; (3) the economic factor; (4) the prophylactic factor; (5) the justice factor. The first was briefly discussed. Space limitations require that the others be dealt with in gross rather than singly, ${ }^{2}$ and in view of this I hastily point the direction taken by each of them.

Probably the moral or ethical factor, best indicated in legal theory by "liability based on fault," is the most compelling influence upon judges when administration offers no obstacles. However hard to subject to definition, the stabilization which the force we call morality gives is not to be doubted. The term is so broad and vague that it threatens to envelop all other factors. Probably for the purposes of this discussion it can best be identified by that partly philosophical, partly religious, partly ethical texture of intellectual tenets which reached their crest in the eighteenth and nineteenth centuries. Here man was a free agent to be left to his own fortunes; he was fully capable of caring for himself ; his conduct was either good or bad; through all things an eternal purpose ran; and all society must be ordered accordingly. Not far behind this moral-fibred ordering are the practical affairs of everyday life. In fact, to what extent the demands of a bread and butter existence control morals themselves is not a soluble inquiry. The two influences are never found divorced. A feudal economy required a morality of trespass; an emerging industrialism a morality of negligence.

But in contrast with both moral and economic factors, which focus primarily upon the past and immediate present, is found a very strong desire on the part of judges, as well as other people, to fashion rules for a healthful future. Judges are inveterate prophets and legislators. They scale their penalties, they impose damages, both punitive and compensatory, not merely for the individual offender's lesson, but as a pre-

1 (1928) 28 Columbia Law Rev. 1014.

2 The difficulties of handling briefly the great mass of materials which lend themselves to this analysis are insuperable. It is probably better to run the story through than to lose it by over elaboration. I have chosen only a small part of the available materials and have refrained from giving references to support many generally accepted propositions. I have frequently cited articles and books rather than give a list of cases. 
ventive of future harms. They spend much time fashioning prophylactic rules both of substantive and procedural design in their efforts to purify the social stream through the judicial process. ${ }^{3}$ Finally, when these other factors are not cramping, judges give attention to the parties before them. They place the loss where it will be felt the least and can best be borne. Despite protestation there is one "law" for the rich and strong and another for the poor and weak. Other factors being in equilibrium, the hurt plaintiff captures the heart of judges and jury alike. This is justice. It is not the usual thing for judges to minister justice, for most frequently procedure, and fault, and business, and future welfare require that justice wait until law has made adjustments on a larger scale. ${ }^{4}$

${ }^{3}$ There are numerous instances of this sort. The decision in McPherson v. Buick Co., 217 N. Y. 382, 111 N. E. 1050 (1916) is a striking one. As an antitoxin to human hurts it ranks along with those which medical science has discovered. It is the same preventive as employed against the manufacturers of drugs and food and electrical appliances, etc. (1928) 38 Y TLE L. J. 399. The "highest practicable degree of care" imposed upon railway carriers of passengers, and the exactions as to spark arresters for preventing fires are for a similar purpose. But these rules are not enough in themselves. Courts have supported them by a so-called "res ipsa loquitur" rule of evidence, a remarkable creation for making effective the administration of the prophylaxis. See Heckel and Harper, Effect of the Doctrine of Res Ipsa Loquitur (1928) 22 ILL. L. Rev. 724. The railway passenger cases were once the normal damage suit, but they are now seldom litigated. The stringent rules in these and similar cases make it useless for defendants to litigate any but the most extreme cases. The habitual use of presumptions as prophylactic measures is of course well recognized. One of the most effective uses of such a makeweight in combination with assessing damages is found in the "chimney sweeper's" case, Armory v. Delemirie, 1 Strange 505 (1722). This case foreshadows the severe "highest intermediate value" rule. See McCormick, Highest Intermediate Value and Damages for Lost Chances (1924) 3 TEX. L. REv. 44. Another instance in a different field is the refusal of the Texas Supreme Court to give countenance to the Massachusetts Trust. This form of business organization lent itself too readily to the "oil frauds" which sprang up in Texas to dupe both residents and non-residents. The court would give it no recognition, although in getting rid of it, great violence had to be done to many well settled principles of law. See Thompson v. Schmitt, 115 Tex. 53, 274 S. W. 554 (1925) and an excellent comment (1928) 37 YALE L. J. $1103,1114$.

${ }^{4}$ One of the best illustrations of the suggestion here made is found in the recent wire tapping cases. Olmstead v. U. S., 48 Sup. Ct. 564 (U. S. 1928). Barely hidden beneath the crust of constitutional phraseology of the majority opinion is the apprehension for the administrative processes of courts if the 4th Amendment is to be given the sweeping scope contended for and if the main lines of a case must be halted to await the determination of incidental issues involving the means of procuring evidence otherwise tellingly relevant. Against this factor Justice Brandeis sets off several different ones: (1) that other phase of administration which requires that it be stopped short of destroying the "liberty" it is designed to protect; (2) the desire to keep the court's scheme of administration in alignment with the progress of science. Here he is emphatic: "The progress of science in furnishing the government with means of espionage is not likely to stop with wire tapping. . . . Advances in the psychic and related sciences may bring means of exploring unexpected beliefs, thoughts and emotions." Ibid. 571 . The need of a preventive against probable future ills weighs heavily with this Justice. Also (3) he added, to these the moral consideration that the government has sought "to avail itself of the fruits" of crimes "to accomplish its own 
Much of the so-called progress made in legal science is of this sort -a realignment of word patterns. The opportunism in making classifications is constantly overlooked. There is no requirement that the legitimacy of a present useful way of looking at the legal set-up must be traceable back into the centuries. Where morals end and economics begin, where prevention against future harms rather than a present justice to the parties before it dominates a court, is candidly the writer's own story. Each of these factors can be translated into any one of the others. Each can be noun or qualifying adjective as taste dictates. They are laid out separately here because they seem of greater importance in that form. They are inseparably intertwined in the earlier centuries, and doubtless they can only be distinguished now because use can be made of such distinctions. And may I indicate at this point that the objective of the discussion is to suggest that the larger problems of legal protection and responsibility are not soluble alone by formulas, doctrines, rules, phrases, definitions, or other devices of dialectic? I anticipate a further suggestion, viz., it is high time that attempts were being made to consolidate the few gains which have been made in dealing with these larger problems, rather than giving energies to the refinement of a technic of detail already obsolescent.

\section{Early Legal Theory}

The early centuries-the twelfth and thirteenth particularly-are dim even to the eyes of a highly equipped historian. ${ }^{5}$ The myths which have grown up about the judicial process of those obscure days never

ends." Ibid. 574. Justice Holmes further bolsters this moral argument by dubbing the practice of paying for and accepting evidence obtained by methods which the government professes to condemn "a dirty business." Ibid. 575. Conservative Justice Butler, not satisfied with the majority view, nor with the contrary view falls back upon the time honored technic of construing "words" and "principles." $\mathrm{He}$ says: "This court has always construed the Constitution in the light of the principles upon which it was founded. The . . . literal meaning of the words used do not measure the purpose or scope of its provisions . . " Ibid. 576. While all of these factors are pressed with the greatest vigor and ability, it is strange that there is not a single reference to the justness of the conviction. Was defendant guilty? Doubtless that was assumed. But justice had to wait until other matters were ironed out. In extenuation it may be said that the "order granting certiorari was to limit the argument to a single question." But Justice Stone aptly closes that escape with the remark: "I do not understand that it restrains the court from a consideration of any question which we find to be presented by the record for .... this court determines a case here on certiorari "with the same power and authority and with like effect, as if the cause had been brought here by unrestricted writ of error or appeal." "Ibid. 576. My comment is not a criticism of this or other courts for making the merits of the individual case await upon these other factors; it is merely to indicate that they do it. Incidentally, the influence of the administrative factor in shaping the rule here in question is neatly developed in a series of recent comments by Richard J. Smith. See (1926-27) 36 Yale L. J. 536, 988 and (1928) 38 YALE L. J. 77.

$\rightarrow$ Woodbine, The Origins of the Action of Trespass (1924) 33 Yale L. J. 799. 
cease to give trouble. ${ }^{6}$ So able a scholar as Dean Ames concluded that "early law is formal and unmoral" and that the "ethical standard of reasonable conduct has replaced the unmoral standard of acting at one's peril." A similar attitude on the part of numerous writers is well stated by Street. " "In the field of trespass liability is based solely upon the fact that damage is directly done by force. No consideration is here taken of the moral qualities of the act which results in damage. The actor may or may not be culpable or morally blameworthy." We have had much legal theory revolving about such terms as "absolute liability," or "acting at peril" as opposed to "liability based on fault" as though they were contradictory. Reconciliations have been thought necessary as though responsibility is less moral when strict and highly moral when excuses are more liberally recognized. ${ }^{9}$ Probably this is more a matter of colorful language than anything else. It is hardly to be imagined that there was ever a time when the particular dispute was settled without reference to the reaction of the community as a whole to the decision. Over and above the hardships which a decision might impose upon a party to the litigation there must have always been a feeling that a general policy was involved. The highest quality of statesmanship is constantly exhibited in the settling of the specific dispute. The judicial process of the common law owes its strength to such statesmanship. It is not any longer venturesome to assume that the judgments of courts in the earlier centuries, like thóse of the present, are only to be understood in the light of the results which the judges thought the social order of the times required. And while there have been constant changes in the weight given the moral factor, as distinguished from the economic and other factors, it is probably nearer the truth to say that such emphasis has lessened rather than grown, and that instead of the responsibility of the earlier centuries being unmoral, it was more strictly moral than that of today. Another way of saying the same thing is that our morality has been expanded and liberalized.

The protection which early common law courts gave to the individual against harms to his interests of personality was given under the action of trespass. ${ }^{10}$ The risks against which protection was given under this action were few. Personal violence, or its threat, was the dominant one. All in all it seems that probably too much weight has

\footnotetext{
- Winfield, The Myth of Absolute Liability (1926) 42 LAw Q. REv. 37.

'Ames, Laze and Morals (1908) 32 Harv. L. Rev. 97; Selected Essays on THE LAW OF TORTS (1924) 1.

1 Street, Foundations Legal Liability (1906) 2.

- Isaacs, Fault and Liability (1918) 31 Harv. L. Rev. 954 (1918); Selected EsSAYS ON THE LAW OF TORTS (1924) 235. 367-370.

${ }^{10}$ Woodbine, The Origins of the Action of Trespass (1925) 34 Yale L. J.
} 
been given the few fragmentarily reported cases and sweeping dicta which appear before the 1800 's as to the arbitrariness with which responsibility was imposed under this action. Dean Wigmore has outlined the development which took place.11 He says: "The evidence seems certain that the rationalization towards the line of present standards began at a much earlier period than has been supposed. In other words, there has never been a time, in English law, since (say) the early 1500's, when the defendant in an action for trespass was not allowed to appeal to some standard of blame or fault in addition to and beyond the mere question of his act having been voluntary; i.e., granting a voluntary act, he might still excuse himself (apart from excuses of self defense, consent and the like)." 12 My only doubt here is that Dean Wigmore has been too conservative and did not set the beginning far enough back, say even before the origin of the action of trespass. ${ }^{13}$ The phrases "acting at peril," "inevitable accident," "utterly without fault," "inevitable necessity" and similar phases, are so vague and general that almost anything can be read into them. The few cases and illustrations of responsibility for unintentional hurts which appear, in so far as the facts are given, could as well as not be instances of highly probable, though unintended, hurts. ${ }^{14}$ There is no reason to suppose that they were not. And the same cases today under our more liberal rules would doubtless entail severe responsibility. When further classification brought trespass on the case into prominence, the question which troubled the courts was not responsibility but whether the action was case or trespass. This is fully illustrated by cases both before and after Scott $v$. Shepherd. ${ }^{15}$ It was only after the distinctions between trespass and trespass on the case became of little practical importance, so far as the protection of bodily integrity against the harms of violence was concerned, that courts were called upon to state with clearness and fullness the excuses and limitations hidden beneath those general vague terms in earlier use. Likewise, it was only then that there was any necessity of making the full distinctions between intentional and negligent hurts. It was the latter class in which the tremendous expansion both of risks and protection came about.

${ }^{11}$ Responsibility for Tortious Acts, Its History (1894) 7 HARv. L. REv. 315, 383, 441; Selected EsSays ON THE LaW OF TORTS (1924) 18 et seq.

${ }^{12}$ At p. 66 of Selected Essays on the Law OF TORTS (1924).

${ }^{13}$ Winfield, op. cit. supra note 6.

${ }^{14}$ See Appendix to Dean Wigmore's concluding article in Selected Essays oN THE LAW OF TORTS (1924) 79. But see HoldSWORTH, History OF ENGLish LAW (1909) vol. 2, pp. 50-52, vol. 3, pp. 375-382.

${ }_{15} 2$ Wm. Bl. 892 (1773). 


\section{Master and Servant Cases}

The negligence network of legal theory was still formative when the industrial adventures of the 1800's were sent forward on so many lines by the use of steam and the numerous mechanical devices which followed its advent. The railroad, the steamboat, the saw mill, the cotton gin, the factories of all descriptions, gave this new legal set up all the work it could do. They likewise gave in the course of the century the old relation of master and servant an entirely new societal significance. ${ }^{16}$ And it is this relation about which so much of the responsibility imposed for unintentional hurts grew up. Here there began a struggle between a legal theory woven of medieval morality and the demands of an ever expanding industrialism which has only now culminated in a victory for the latter. Fogs were never thicker than those produced in the thinking of judges about the protection which should be given against the risks to which the interests of personality were subjected by such developments. When the master-servant cases first began to come before the courts, it must be remembered that the negligence theory was freshly spun. The idea had emerged definitely through the action on the case. It had come into conflict with the action of trespass and trespass was giving ground before it rapidly. ${ }^{17}$ Assumed risk had found a place as a defense. ${ }^{18}$ As late as 1820 it had served to defeat an action against a landowner who had set spring-guns in the wood into which plaintiff had walked, knowing that there were guns in the wood. ${ }^{19}$ Contributory negligence had begun to emerge as a distinct sort of assumed risk. ${ }^{20}$ "The ordinary prudent man" had been definitely brought

\footnotetext{
${ }^{16}$ See Beard, Whither Mankind (1928) c. V (Labor), by Sidney and Beatrice Webb.

${ }^{17}$ Leame v. Bray, 3 East 593 (1803) ; Wakeman v. Robinson, 1 Bing. 213 (1823); Sharrod v. Ry. Co., 4 Ex. 584 (1849); Holmes v. Mather, L. R. 10 Ex. 261 (1875).

${ }^{18}$ Cruden v. Fentham, 2 Esp. 685 (1799); Clay v. Wood, 5 Esp. 44 (1803);

$\rightarrow$ Bohlen, Voluntary Assumption of Risk (1906) 20 HaRv. L. Rev. 14, 19; SeLected EsSAYs ON THE LAW OF TORTS (1924) 497.

${ }^{10}$ Ilott v. Wilkes, 3 B. \& Ald. 308 (1820). Many interesting arguments indicating strong practical tendencies were made by the judges in this case. Although the guns were merely set to prevent trespasses and not to preserve game, Best, J., makes this argument: "If you do not allow men of landed estates to preserve their game, you will not prevail on them to reside in the country. Their poor neighbours will thus lose their protection and kind offices; and the Government, the support that it derives from an independent, enlightened and unpaid magistracy." Ibid. 320. Compare the equally strong moral argument of the same judge in Bird v. Holbrook, 4 Bing. 628, 641-643 (1828) (a spring gun case in which plaintiff had no notice) ... but there is no act which Christianity forbids, that the law will not reach; if it were otherwise, Christianity would not be as it has always been held to be, part of the law of England. . . . But we want no authority in a case like the present; we put it on the principle that it is inhuman to catch a man by means which may maim him or endanger his life, and, as far as human means can go, it is the object of English law to uphold humanity and the sanctions of religion."
}

${ }^{20}$ Butterfield v. Forrester, 11 East 60 (1809). 
over from the bailment cases. ${ }^{21}$ Davies $v$. Mann $^{22}$ as a limitation upon the newly discovered defense device of contributory negligence was just in the offing.

The master had long been responsible to third persons for unintentional hurts caused by a servant's conduct, but he had never been called to account to a servant for negligent hurts caused either by another servant or the master himself. A servant had assumed the risks of his employment. ${ }^{23}$ Only at a very late date and in the most extreme cases was the servant given relief even against the harms intentionally inflicted upon him by the master. ${ }^{24}$ Unintended harms were wholly out of the question as a basis of responsibility.

This was the background for Priestly $v$. Fowler in 1837.25 The case was very simple. Plaintiff, a servant, had received injuries to his person on account of the defects in a van which had been overloaded, both the defects and overloading being alleged to be due to the negligence of the defendant, so that when the van broke down the plaintiff was thrown with violence to the ground. Plaintiff had judgment, and rule was obtained to show cause why the judgment should not be arrested, on the ground that defendant was not liable in law under the circumstances stated in the declaration. Every benefit was given to the pleading, and Lord Abinger, speaking for the court of Exchequer recognized the responsibility of a master for the acts of his servant, but held there was no responsibility in this case. He said:

"It is admitted that there is no precedent for the present action by a servant against a master. We are therefore to decide the question upon general principles, and in doing so we are at liberty to look at the consequences of a decision the one way or the other.

If the master be liable to the servant in this action, the principle of that liability will be found to carry us to an alarming extent. He who is responsible by his general duty, or by the terms of his contract, for all the consequences of negligence in a matter in which he is the principal, is responsible for the negligence of all his inferior agents. If the owner of the carriage is therefore responsible for the sufficiency of his carriage, he is responsible for the negligence of his coachmaker, or his harnessmaker, or his coachman."

Thus Lord Abinger argues that to allow this action will be letting the master in for a great responsibility indeed. For, if the master is liable, for his own negligence, he will be liable for his servant's negli-

${ }^{21}$ Vaughn v. Menlove, 3 Bing. N. C. 468 (1837).

${ }^{22} 10$ M. \& W. 546 (1842).

${ }^{23}$ Southcote v. Stanley, 1 H. \& N. 247 (1856)

2 See 1 Labatt, Master \& Servant (2d ed. 1913) § 256.

${ }_{25} 3$ M. \& W. 1 (1837). 
gence also. The economic disruption of the domestic establishment as visioned by this judge cannot be portrayed save in his own words. $\mathrm{He}$ continues :

"The footman, therefore, who rides behind the carriage, may have an action against the master for a defect in the carriage, owing to the negligence of the coachmaker, or for a defect in the harness arising from the negligence of the harnessmaker, or for drunkenness, neglect, or want of skill in the coachman; nor is there any reason why the principle should not, if applicable in this class of cases, extend to many others. The master, for example, would be liable to the servant for the negligence of the chambermaid for putting him into a damp bed; for that of the upholsterer, for sending in a crazy bedstead, whereby he was made to fall down while asleep and injure himself; for the negligence of the cook in not properly cleaning the copper vessels used in the kitchen; of the butcher, in supplying the family with meat of a quality injurious to the health; of the builder for a defect in the foundation of the house, whereby it fell, and injured both the master and the servant by the ruins. The inconvenience, not to say the absurdity of these consequences, affords a sufficient argument against the application of this principle to the present case."

Thus Lord Abinger parades the dreadful economic consequences of such a principle to foreclose any hope servants might have had for compensation for hurts received in the service of their masters. But not satisfied with this argument, he resorts to a long recognized legal doctrine :

"But, in truth, the mere relation of the master and the servant never can imply an obligation on the part of the master to take more care of the servant than he may reasonably be expected to do of himself. ... The servant is not bound to risk his safety in the service of his master, and may, if he thinks fit, decline any service in which he reasonably apprehends injury to himself; and in most of the cases in which danger may be incurred, if not in all, he is just as likely to be acquainted with the probability and extent of it as the master."

The court would invoke against the servant-a free agent-the defense of assumed risk in both its original form and as developed under the new doctrine of contributory negligence. But of most striking significance is this final psychological argument:

"In fact, to allow this sort of action to prevail would be an encouragement to the servant to omit that diligence and caution which he is in duty bound to exercise on the behalf of his master, to protect him against the misconduct or negligence of others who serve him, and which diligence and caution, while they protect the master, are a much better security against any injury the servant may sustain by the negligence of others engaged under the same master, than any recourse against his master for damages could possibly afford." 
Thus was used the final argument which has been used in so many cases in which the courts are anxious to set up some rule which will purge and purify the conduct of human beings in their contacts. It is the judicial prophylaxis. Here by denying recovery to servants injured by the negligence of other servants, the maximum of protection would be exacted in behalf of their master's interests in order that they themselves would not be hurt. By virtue of the desire of self preservation servants would be purged of their carelessness, and their conduct purified by the caution of self interest. A capital argument: And of all the subsequent cases, few, if any, got beyond the factors here relied upon, and in none were they stated more convincingly. Probably they were too convincing inasmuch as courts continued to rely on the arguments long after the factors beneath had fallen into radically different alignment. But notice that in this original case there was not a word spoken about the risk-bearing capacity as between the two parties to the litigation. As usual the court was more interested in the economy of the day-in principle-in rule making-in theory-than in justice. The complexity of human affairs constantly calls for just such treatment. Courts administer "law," the power of society to order itself ; justice is one of the factors which determine how that power should be administered.

Two master-servant cases arose almost immediately after Priestly v. Fowler; one in South Carolina, ${ }^{26}$ the other in Massachusetts. ${ }^{27}$ Both cases involved injuries to railroad operatives by the negligence of other employees. Apparently without having the benefit of the English precedent, the South Carolina court reached the same conclusion and stressed the same factors with about the same emphasis. The same principles were held to govern the risks arising out of the new adventure of railroading as governed those incident to operating a van. For approximately half a century it apparently did not occur to lawyers that the assumptions (principles) at the basis of the masterservant relation with reference to horse drawn vehicles were inadequate as a basis of the same relation in railroad operations. ${ }^{28}$ Chief Justice Shaw for the Massachusetts court accepted both the conclusions and reasoning of the other two courts. He probably stressed even more than Lord Abinger the desirability of such a rule in order to protect the

${ }^{26}$ Murray v. South Carolina R. R., 1 McMullan's Law 385 (1841).

${ }^{27}$ Farwell v. The Boston \& Worcester R. R., 4 Met. 49 (Mass. 1842).

${ }^{28}$ One of the first protests is found in the opinion of Byles, J., in Clarke v. Holmes, 7 H. \& N. 937, 947 (1862). He says: "But the principles laid down in Priestly v. Fowler, and all the examples there given of their application, relate to the conveniences and casualties of ordinary or domestic life, and ought not to be strained so as to regulate the rights and liabilities arising from the use of dangerous machinery." 
servant against the negligent conduct of his fellows. With this case the "fellow servant" doctrine became well settled, and probably no limitation upon the negligence theory of liability was ever employed so successfully. The English courts further emphasized it and the American courts did likewise. ${ }^{29}$ The name itself indicates that the voluntary assumption of risk was the dominant idea in this defense, although the other ideas stressed by Lord Abinger furnished substantial support.

The same idea was at the basis of other defenses to actions by servants. In any case of this type if the servant knew the conditions of his employment, or was in a position where he should know the conditions as well as the master, he was held to have assumed the risks incident to such employment. The negligence of fellow servants was merely a part of this larger doctrine of assumed risk, ${ }^{30}$ which was given the broadest application for many years. ${ }^{31}$ In fact there was very little need of translating the risks to which servants were subjected into terms of contributory negligence until much later,,$^{32}$ but when that was done the assumption of risk idea was given its largest extension. It is generally stated that contributory negligence is something distinct from assumed risk, ${ }^{33}$ but it is believed that such opinion is due to the refine-

${ }^{29}$ Pollock, C. B., in Vose v. The Lancashire v. Yorkshire Ry., 2 H. \& N. 728,734 (1858), said: "Few rules of law are of greater practical importance. The law must have been the same long before it was enunciated in this court in the case of Priestly v. Fowler. . . . If not, such actions would have been of frequent occurrence. No such action, however, appears ever to have been brought before the decision of that case. We ought not to allow so important a decision to be frittered away by minute distinctions or the ingenuity of advocates."

${ }^{30}$ Alderson, B., in Hutchinson v. The York, Newcastle and Berwick Ry., 5 Ex. 341, 351 (1850) said: "The principle is, that a servant, when he engaged to serve a master, undertakes, as between him and his master, to run all the ordinary risks of the service, and this includes the risk of negligence on the part of a fellow servant, whenever he is acting in discharge of his duty as servant of him who is the common master of both."

${ }^{31}$ Skipp v. The Eastern Counties Ry., 9 Ex. 223 (1853) ; Dynen v. Leach, 26 L. J. (N. s.) Ex. 221 (1857) ; Woodley v. Metropolitan District Ry., 2 Ex. D. 384 (1877); Clarke v. Holmes, 7 H. \& N. 937 (1862). See 17 Law Notes 206 (Am. 1914.)

${ }_{32}$ There are very few cases of contributory negligence on part of servants prior to 1870 . See Senior v. Ward, 1 El. 385 (1859); Clark v. Holmes, 7 H. \& N. 937 (1862); Brown v. Maxwell, 6 Hill 592 (N. Y. 1844). In WharToN, NeGLIGENCE (1874) there are very few early cases cited. See $\$ 244$. In SHEARMaN \& REDFIELD, NEGLIGENCE (3d ed. 1874), there are few such cases. But in the 4th edition (1888) there are several sections devoted to the subject. See $\$ 207$ et seq. There are also many then recent cases cited. Of more significance is the change of the whole attitude of these writers on the general defense of assumed risk. They say: "This principle is, that the exemption of masters from liability to servants, for injuries caused by defects which the servants knew or ought to have known, is founded solely upon the general law of contributory negligence. . Ibid. §208; also see \$§ 177-180. BEACH, CoNTRIBUTORY NEGLIGENCE (1885) recites the rule that a servant's contributory negligence is a bar to the servant's action, but the cases cited are all recent. See $\$ 94$ et seq.

${ }^{3}$ See Bohlen, Contributory Negligence (1908) 21 Harv. L. Rev. 233; VoLuntary Assumption of RIsk (1907) 20 ibid. 14; Schofield, Theory of Contributory Negligence (1890) 3 ibid. 263; BEACH, op. cit. supra note 32, §§6, 8. 
ments made necessary by the numerous doctrinal conflicts of the late 1800 's. $^{34}$ Contributory negligence is merely a label for the sorts of assumed risks apposite to negligence. This term doubtless sounded less harsh and more righteous, especially at a time when assumed risk was being pushed to the furthest extreme by the English courts. It looks like using the same idea as a defense against the plaintiff as was used by him against the defendant. It had all the appearances of fair play. But in fact it developed into the harshest defense the courts have ever recognized. An admitted wrongdoer was completely absolved from his wrong at the expense of the injured party.

Closely bound up with the idea of assumed risk was the further idea of "proximate cause." It had never played a part in intentional harms. ${ }^{35}$ The legal theory behind trespass was too transparent to give much place to "causes." But when the negligence concept was developed, and the defense of contributory negligence arose, thus introducing multiple fault factors, it was inevitable that this partly philosophical, partly moral, attempt to trace out responsibility in terms of causes should receive great emphasis. Thus instead of "proximate cause" being a possible basis of contributory negligence as has been suggested, ${ }^{36}$

${ }^{34}$ See 3 LABATT, op. cit. supra note $24, \S 1223$ for indication of the confusion between the two defenses and for an attempt to discriminate them. See 17 Law Notes 206 (Am. 1914); also (1928) 37 Yale L. J. 831.

${ }^{35}$ I do not overlook Vicars v. Wilcock, 8 East 1 (1806) nor Ward v. Week, 7 Bing. 211 (1830), nor cases of that type which were dealing with the problem of limiting liability in intentional harms under the "natural and probable consequence" formula. See Bohlen, Contributory Negligence (1908) 21 Harv. L. REv. 233; Beale, The Proximate Consequences of an Act (1920) 33 ibid. 633. This formula was taking form somewhat earlier than the "proximate cause" formula in negligence cases. These formulae soon became so interwoven that they could no longer be easily identified, but that was later in the century. The first very serious suggestion in English cases I have found of the two ideas being thought of as one is Pollock's dicta in Rigby v. Hewitt, 5 Ex. 239, 249 (1850) and in. Greeland v. Chaplin, 5 Ex. 243 (1850). Before this Greenleaf in his book on EvIDENCE (2d ed. 1848) $\$ 256$ had said: "The damage to be recovered must always be the natural and proximate consequence of the act complained of. This rule is laid down in regard to special damages, but it applies to all damages" (citing SEDGwICK, DAmAges [1869] c. iii). Both Greenleaf and Sedgwick are cited for this proposition in several early cases. See SeDGwICK, DAmages (5th ed. 1869). None of these cases and none of those relied on by these authors involve causation but are cases dealing with limitations upon responsibility in intentional hurts in tort cases or in breaches of contract, usually dealt with as special damages, or remote or consequental damages, all terms of very long standing. Sedgwick seems to have been the first to associate the two ideas. He says (ibid. 56), evidently bringing forward an earlier statement: ". . . the law refuses to take into consideration any damages remotely resulting from the act complained of. This proposition, or one correlative to it is expressed in the maxim causa proxima, etc.' But on page 65 he says: "Mr. Greenleaf has said with more accuracy (quoting the sentence set out above from § 256)." The phrase struck the imagination of many courts. But clearly he was talking about the older problem, and not the one set up in Butterfield v. Forrester, supra note 20 . The association of two ideas has seldom caused so much trouble.

${ }^{36}$ See Bohlen, op. cit. supra note 35. Professor Beale makes the statement in his article (op. cit. supra note 35 , at p. 636) that "in very few cases up to the 
it is the most extravagant development of that ruthless defense. But it did not play much part in master-servant cases until contributory negligence had taken over many of the defensive grounds which had previously been recognized under assumed risk. Thus it was that as late as Thomas v. Quartermaine ${ }^{37}$ Bowen, L.J., could express the normal view of his century concerning the doctrine: "Contributory negligence in a plaintiff only means that he himself has contributed to the accident in such a sense as to render the defendant's breach of duty no longer its proximate cause." Thus could contributory fault be translated into "proximate cause." In this way the pain given by the contributory negligence defense was somewhat dissipated by an anaesthetizing phrase. What is more, the "last clear chance" limitation, itself a countervailing morality upon that of contributory negligence, but further accentuated the development of this least intelligible of all the doctrines of the negligence network. ${ }^{38}$ Although "proximate

year 1900 is the proximity of the cause the subject of investigation." It is not clear what is meant by this statement. The "proximate cause" doctrine had raged throughout the $1800^{\prime}$ s after the rule in Butterfield v. Forrester, supra note 20 , became the vogue. That case itself was not radical. It was a case of subsequent negligence on plaintiff's part, the exact converse of the Davies and Mann situation more than thirty years later. It was accepted for a broader principle which included concurrent negligence on part of plaintiff and defendant. This marks the normal danger of principles: they are always stated more broadly than the case or else a new one is required for each case. As a result of the broad principle of this case, courts began tracing out the results of the respective faults of both plaintiff and defendant. At first it was done mildly. In Flower v. Adams, 2 Taunton 314 (1810), plaintiff's inability to handle his horse which was frightened by defendant's ashes, was held by Lawrence, J., "to be the immediate and proximate cause." Then followed, Vennal v. Garner, 1 C. \& M. Ex. 20 (1832); Hawkins v. Cooper, 8 C. \& P. 473 (1838); Woolf v. Beard, 8 C. \& P. 373 (1838); then came the stronger statement of Parke, B., in Bridge v. The Grand Junction Ry., 3 M. \& W. 244, 248 (1838): “. . . if by ordinary care he might have avoided them, he is the author of his own wrong." This was repeated in Davies v. Mann, 10 M. \& W. 546 (1842), and quoted in many subsequent cases. Smith v. Dobson, 3 Man. \& G. 59 (1841) marked further emphasis, and so did Greeland v. Chaplin, 5 Ex. 243 (1850). By the time of Dowell v. Steam Navigation Co., 5 E. \& B. 194 (1858), the use of "proximate cause" is well in the vocabulary. Among Chief Justice Campbell's many uses of the term is this: "If it (plaintiff's fault) was a proximate cause of the collision, however much the steamer might be in fault, this action cannot be maintained." Subsequent cases make great use of the term. See Tuff v. Warman, 2 C. B. (N. s.) 739 (1857); same case 5 C. B. (N. s.) 573 (1858); Witherley v. Regents Canal Co., 12 C. B. (N. S.) 2 (1862). In the meantime the term had become current in American opinions. American text writers during the last 25 years of the century indicate what a large part it played in legal theory. See SHEARMAN \& REDFIELD, NeGLIGENCE (3d ed. 1874) \$\$ 8-10, 33; ibid. (4th ed. 1888) cc. II, VI; WharTon, op. cit. supra note 32, c. III (Causal Relation), c. IX. (Contributory Negligence). It is doubtless a good guess that Wharton did more than any one else to disseminate this vicious doctrine in its most pernicious form. BEACH, $o p$. cit. supra note $32, \S \S 10,11$. The doctrine had been elaborated in multitudes of cases during the century and had reached a most intricate development before its end.

\footnotetext{
18 Q. B. D. 685,694 (1887).

${ }^{38}$ Davies v. Mann and subsequent cases cited in supra note 36.
} 
cause" did nothing to extend responsibility, it proved one of the severest restrictions on imposing responsibility. It is mentioned here merely to call attention to the fact that to an already waterlogged morality theory of responsibility was added an additional deadweight of moral mysticism. Nor was this enough. There still remained that defensive strand of vicariousness-imputed negligence ${ }^{39}$ - to be woven into this steadily darkening legal theology.

But this multiple array of defensive moralities was too powerful and the courts quickly put limitations upon them. The so-called nondelegable duties were the most important of these. ${ }^{40}$ A servant did not assume the risks of his fellows' negligence if the master were negligent in employing competent fellow servants. Nor did a servant assume the risks due to poor rules and organization, dangerous surroundings and defective machinery, if the master was negligent in these particulars. ${ }^{41}$ The master's duties under these heads seemed to take many directions, but they were in fact merely devices for escaping the drastic defenses which had been put into the hands of masters. And when in time these duties upon the master pressed too heavily against the basic morality of the defenses, the courts again put limits on them. The result was that the servant who entered upon his work or continued to work after knowing about the incompetency of his fellow servants, the inadequacy of the system of work, or the dangerous nature of the surroundings or the defective machinery, or any other failure of the master to perform his duties for the servant's protection, again encountered the defenses of assumed risk and contributory negligenceas best suited the dialectic of the occasion. In some cases, where the master promised to repair a defect, or there was an emergency of one sort or another, further refinements were made to save the injured servant, but it was hard for him to escape these twin-moralities of assumed risk and contributory fault. Also in constantly expanding industrial organizations it was not always easy to tell who were fellow servants. There were multitudes of employees of numerous ranks and classes. Obviously they could not all be treated on an equal footing. Many tests were required to make necessary distinctions: the vice principal doctrine, the departmental theory, the superior officer test, and the very important non-assignability of duty test. Every imaginable means of balancing the moral notions which dominated the negli-

${ }^{39}$ Thorogood v. Bryan, 8 C. B. 114 (1849) ; County Commissioners v. Beulah, 138 Atl. 25 (Md. 1927); Brown v. Schendelman, 143 Atl. 42 (Del. 1928); Hazel v. Hooperton, 310 I11. 38, 141 N. E. 392 (1923). See excellent note (1926) 74 U. OF PA. L. Rev. 86.

${ }^{40}$ See 3 LABATt, op. cit. supra note 24 , c. XXXV.

11 See Huffcut, Agency (2d ed. 1901) § 276. 
gence theory of the 1800 's and setting off one against the other must have been resorted to. There is no way to exaggerate what actually took place. The only complex negligence doctrine which was rejected even in part was the "degrees of negligence" device which was given so large currency by Sir William Jones' little book on Bailments in the late 1700 's. ${ }^{42}$ It is hard to understand why so practical an adjustment as the "comparative negligence" suggestion fell by the way so quickly. ${ }^{43}$ Probably it was due to the violent reaction against the difficulties of the "degrees of negligence" that this one rational idea of the whole mass of moral rules was rejected so peremptorily. Nineteenth century morality was a severe thing. It demanded absolutes. Either a defendant was responsible or he was not. Compromises were not to be endured. Nor could the courts bear to see so much legal theory swept aside by a simple device of apportioning the damages and that done by laymen. A moral century required the balancing of moral formulas at the hands of experts in morality. Let it suffice to say that legal theory based on the notions underlying assumption of risk, buttressed by the arguments of domestic economy, and chastity of conduct born of hardship, as set forth by Lord Abinger, could be and was spun indefinitely.

There is only one bright spot. Whenever a case for any reason broke through legal theory and reached the jury it was almost invariably decided against the master and for the servant. And what is more, the judges, both trial and appellate, found themselves so enmeshed in their theories that their only retreat in many cases was found in passing the matter to the jury. The superstructure of theory broke under its own weight. Verdicts were too constant and too overwhelming to be withstood except in the most haphazard fashion. And the jury probably rendered the most important of its scanty service to legal science at this juncture. Seemingly, juries saw only the parties before them, and placed the risk where they thought it could best be borne. The judges had been interested in principles; juries were interested in doing justice between the parties. The judges evolved a nice scheme for determining

${ }^{42}$ Hinton v. Dibbin, 2 Q. B. 646, 661 (1842) ; Wells v. N. Y. Central R. R., 24 N. Y. 181 (1862). See Shearman \& REDFIELD, NEGLIGENCE (3d ed. 1874) c. II; (4th ed. 1888) c. III. The terms "gross" and "wilful" negligence are constantly used, and serve a good purpose, as makeweights to avoid the effects of contributory negligence and in place of the "last clear chance" phraseology. They are used to extend the latter doctrine in jurisdictions which only purport to recognize the "discovered peril" branch of the doctrine. See my discussion, Contributory Negligence and Proximate Cause (1927) 6 N. C. L. REv. 3, 26, 27. See excellent article by F. Green, High Care and Gross Negligence (1928) 23 ILL. L. Rev. 4.

${ }^{4} \mathrm{~S}$ See cases cited in AMES \& SMITH, CASES ON TORTS (Pound's ed. 1917) 267-268; BEACH, op. cit. supra note 32, c. III, Comparative Negligence. See Pollock's remark in Greeland v. Chaplin, 5 Ex. 243 (1850). What the courts refused to undertake as impossible, they now do in nearly every state by virtue of some statute. 
responsibility, the juries gave verdicts which wrecked the scheme. Juries held their ground here until legal theory could catch up with the new order of things which had emerged under the very eyes of the judges without most of them noticing it. But these theories had been developed under severe difficulties and were not to be cast aside without protest, for judges and lawyers had found them fascinating to create and to work with. And what is more, they are still respectable. ${ }^{44}$

The first Employers' Liability Act was passed by Parliament in 1880. By a divided court this act was construed to relieve the servant only of the "fellow-servant" defense. ${ }^{45}$ Bowen, L.J., said: "The true view in my opinion is that the Act . . has placed the workman in a position as advantageous as, but no better than, that of the rest of the world who use the master's premises at his invitation on business." Both the defenses of assumption of risk and contributory negligence were otherwise left intact. In 1891 the House of Lords in Smith $v$. $B a k e r^{46}$ gave some relief against the defense of assumed risk when invoked to defeat the action of a servant who had continued to work after knowing the danger. But the full lesson taught by the cases of this class which had come before the court was not appreciated until the Workmen's Compensation Act of 1906. ${ }^{47}$

In America legislatures were contented with passing very restricted employers' liability acts applicable primarily to railroads, and even these were restricted in numerous particulars by the courts where they were allowed to stand at all. ${ }^{48}$ In 1911 the early workmen's compensation act of the New York Legislature came before the New York Court of Appeals ${ }^{49}$ and was held unconstitutional. While the court recognized that the defenses of contributory negligence and the fellow servant rule could be abolished by legislation, it denied the legislative power to make an employer responsible for injury incurred without the fault of the employer. The court said:50

${ }^{44}$ Moore v. Isenman, 143 Atl. 462 (Me. 1928); Zuverino v. Boston \& M. R. R., 143 Atl. 308 (Vt. 1928); Flannery v. New York, O. \& W. R. R., 29 F. (2d) 18 (C. C. A. 2d, 1928); New York, C. \& St. L. R. R., 164 N. E. 288 (Ind. App. 1928).

${ }^{45}$ Thomas v. Quartermaine, 18 Q. B. D. 685 (1887).

48 [1891] A. C. 325.

"Knowles, Law Relating to Workmen's Compensation (4th ed. 1924).

${ }^{4}$ See Buford, Assumption of Risk Under the Federal Employers' Liability Act (1915) 28 HaRv. L. Rev. 163; Second Employers' Liability Cases, 223 U. S. 1; 32 Sup. Ct. 169 (1912); (1928) 37 Yale L. J. 831. The Supreme Court still maintains a none too liberal attitude towards cases which might well be held to fall within the Employers' Liability Act. See Unadilla Valley Ry. v. Caldine, 49 Sup. Ct. 91 (U. S. 1928); Kansas City So. Ry. v. Jones, 48 Sup. Ct. 308 (U.' S. 1928).

4ves v. South Buffalo Ry., 201 N. Y. 271, 94 N. E. 431 (1911).

${ }^{50}$ Ibid. 293, 94 N. E. at 439. 


\begin{abstract}
"When our constitutions were adopted, it was the law of the land that no man who was without fault or negligence could be held liable in damages for injuries sustained by another. That is still the law. . . The argument that the risk to an employee should be borne by the employer because it is inherent in the employment may be economically sound; but it is at war with the legal principle that no employer can be compelled to assume a risk which is inseparable from the work of the employee, and which may exist in spite of a degree of care by the employer far greater than may be exacted by the most drastic law."
\end{abstract}

This but indicates how deeply ingrained this idea of "fault" had become in the thought habits of judges. But they could not hold out. Industry had grown rich beyond belief. The risks of physical hurts could be distributed as well as could wages and other costs. Business no longer required protection against its workmen as did the household of Lord Abinger's century. The dangers incident to employment were such that the most intelligent and loyal service could not prevent them. On the other hand workmen had become even more dependent upon the mercy of avaricious industrialists who would not of their own accord provide the preventive safeguards which were within their command. It was now seen that the power of society was needed to compel employers to purge their conduct towards their employees rather than the reverse. Juries had already forced the courts to do for years what the Court of Appeals of New York held the legislature had no power to do. The idea of "fault" in any moral sense in these cases had become bankrupt. Justice between the injured workman and his employer had been forced into the picture and once it had made itself recognized it was found to be in full harmony with the economics of industry. Whether it be called a liberalized ethical notion of responsibility, or a responsibility compelled by giving heed to other factors than those of morality, a new order of things was at hand. And the administration of this new scheme demanded a different technic from that of the orthodox courts-a technic untrammelled by the theories of administration which have so successfully strangled the courts when faced with large developments as the employee emancipation.

\title{
Landowner and Intruder
}

The negligence network of legal theory has been hastily sketched as it developed in master-servant cases as a pattern by which to indicate other developments either mature or now under way. The possibilities are many but the briefest outlines must suffice. Again familiar subject matters are chosen. 
Land has an indefinite extent upwards as well as downwards. ${ }^{51}$ The owner may use his land as he pleases short of creating a nuisance. ${ }^{52}$ Every entry thereon without the owner's leave is a trespass for which the owner may have his action. ${ }^{53}$ The owner owes a trespasser no duty other than not to intentionally harm him. ${ }^{54}$ No group of ideas has been harder set in the pronouncements of courts. Even the strong morality of the negligence theory has made slow progress against the landowner's preferential position. Assuming that by a process of "peaceful penetration" it has practically superseded the older concepts with reference to the uses made by a landowner of his property, negligence cannot yet wear its own garb. Unreasonable uses must still be spoken of and dealt with in terms of nuisance, ${ }^{55}$ and intruders on land are classified into multiple useless and confusing categories. ${ }^{56}$ But the question now has come to be, not whether the negligence process should be recognized as controlling the landowner, but whether he should not be controlled, in many instances at least; by even a more rational process for imposing responsibility.

${ }^{51} 2$ Bl. Coмm. *18; see Ball, The Jural Nature of Land, 23 ILL. L. Rev. 45 $(1928 \rightarrow$ The Vertical Extent of Ownership in Land (1928) 76 U. of PA. L. Rev. 631.

${ }_{52}$ Sic utere tuo ut alienum non laedas, 3 BL. Coмm. *217; Blythe v. Topham, 1 Roll. Abr. 88, Cro. Jac. 158 (1607). See Shearman \& Redfield, Negligence (3d ed. 1874) §496.

${ }^{53} 3$ BL. Com M. *209; Dougherty v. Stepp, 18 N. C. 371 (1835).

54 Ilott v. Wilkes, supra note 19; Buch v. Amory Mfg. Co., 69 N. H. 257, 44 At1. 809 (1898); Bohlen, Studies in the LaW of ToRts (1926) 156.

${ }^{55}$ Beecher v. Dull, 143 Atl. 498 (Pa. 1928); (1929) 77 U. of PA. L. Rev. 550; McFarlane v. City of Niagara Falls, 247 N. Y. 340, 160 N. E. 391 (1928). The court in the latter case says: "Nuisance as a concept of law has more meanings than one. The primary meaning does not involve the element of negligence as one of its essential factors (Heig v. Licht, $80 \mathrm{~N}$. Y. 579). One acts sometimes at one's peril." Ibid. 343,160 N. E. at 391 .

It could be said as easily that it is unreasonable (negligent) to act at all in such cases. This is the position taken by Jeremiah Smith in the blasting cases. $\mathrm{S} \rightarrow$ Smith, Liability for Substantial Physical Damage to Land by Blasting (1920) 33 Harv. L. Rev. 542, 549; Selected Essays on The Law of Torts (1924) 614,621, 633. See also 1 Thompson, Negligence (1901) $\$ 675$.

${ }^{58}$ The numerous categories of persons who may go upon land, ranging from a naked trespasser to a business guest, are of relatively recent origin, having developed simultaneously with the negligence theory of responsibility as a whole. They were invented to make the negligence concept more adaptable to the landowner's control. See Shearman \& Redfieid, Negligence (3d ed. 1874) c. XXVIII. The courts took over the trespass idea, a moral notion employed since the earliest developments of the common law, and made it serve the purpose of a stem on which to graft this whole new scheme of categories. The negligence formula of reasonable care was slow in taking form; it was vague at best. When applied to the infinite situations of the landowner towards persons coming on his land, it seemed to place far more power in the hands of a jury than the judges of the middle $1800^{\prime}$ s were willing to pass over to them. The expression of Pollock, C.B., in Hardcastle v. South Yorkshire Ry., 4 H. \& N. 67 (1859) reflects what was said both before and after in these cases: "We do not see where the liability is to stop ... . it would be very dangerous . . . if in every case it was to be left as a fact to the jury, whether the excavation 
The most striking instance of this class of cases is probably found in the case of intrusions made by young children upon the premises of industrial land owners. The trespasser rule has had its bloodiest toll at this point. ${ }^{57}$ The landowner's responsibility was denied first because the intruder himself was a wrongdoer and there was no duty owed him, and in the absence of duty the idea of negligence was beside the point. ${ }^{58}$ A majority of courts conceded this ground but met it with a like moral argument. They said that the landowner who places danger-

were sufficiently near to the highway to be dangerous." No one can read these cases without feeling the strong fear that landowners must be protected from juries. See Binks v. The South Yorkshire Ry. and River Dun Co., 3 B. \& S. 242 (1862); Hounsel v. Smyth, 7 C.B. (N.s.) 729 (1860); Southcote v. Stanley, 1 H. \& N. 247 (1856); Bolch v. Smith, 7 H. \& N. 736 (1862) (no duty to licensee as to obvious danger); Gautret v. Egerton, L. R. 2 C.P. 371 (1867). Even as strong a case as Barnes v. Ward, 9 C. B. 392 (1850) gave the judges a great deal of trouble.

In this formative period of negligence theory judges found that by classifying the persons into various classes they could more effectually control the power of the jury. The more classes, the more necessity of defining those classes, the more "duties" to be determined (the duty concept is the judge's contrivance through which to exercise his power), and thus the fewer cases to be sent to a jury, and the more binding the instructions which accompanied the cases which were sent. It was thus an administrative device. But the results are distressing. These nice grades of persons represent the same idea as the degrees of negligence which were also based on classification of persons. They are more difficult because there are more of them and they are more deceptive in appearance. Except in the easy cases, in which no classification is needed in order to pass judgment, it is harder to determine what class the person falls in than it is to decide the case. If courts generally recognized the fact that it was perfectly legitimate for them to classify the person according to the judgment they desired to reach, I should find little criticism of the scheme. But frequently they wrestle so hard in getting their person into the desired classification that not only are their own judgments clouded, but others who would rely on such judgments for guidance come also to take them seriously. For illustration see Sweeny v. Old Colony R. R., 10 Allen 368 (Mass. 1865); Brigman v. FiskeCarter Construction Co., 192 N. C. 791, 136 S. E. 125 (1926). The trouble with such classification is that it seems to make judgment depend upon one factor alone, and this is wholly misleading. There are numerous factors found in nearly all of these cases, such as the nature of the premises, the extent of the danger, the age of the person, his physical capacity, his intelligence generally and his acquaintance with the particular situation, the occasion for his visit, and many others. The cases themselves reflect the monstrous results, both in legal theory and protection afforded particular persons, growing out of the attempt to focus judgment on the one factor of whether the intruder was a trespasser, licensee, invitee, business guest or some one of the sub-classes under each of these. See Colbert v. Holland Finance Co., 164 N. E. 162 (Ill. 1928), for strange use of "doctrine of invitation."

$\rightarrow$ Smith, Liability of Landowners to Children Entering Without Permission (1898) 11 Harv. L. Rev. 349, 434; Selected Essays on The Law of Torts (1924) 357; Hudson, Turntable Cases in the Federal Courts (1923) 36 HaRv. L. Rev. 827; Selected Essays on The Law of Torts (1924) 397. See lists of cases at the conclusions of these articles. See also many other articles cited in WILSON, CASES ON TORTS (1928) 543.

${ }^{88}$ Buch v. Amory Mfg. Co., supra note 54; D. L. \& W. R. R. v. Reich, 61 N. J. L. 635,40 At1. 682 (1898); Ryan v. Towar, 128 Mich. 463,81 N. W. 644 (1901); Cox v. Alabama Water Co., 112 So. 352 (Ala. 1927) ; Dobbins v. Missouri, etc., R. R, 41 S. W. 62 (Tex. 1897); Kaproli v. Central R. R., 143 Atl. 343 (N. J. 1928) 
ous and attractive machinery on his land thereby tempts young children, and his temptations amount to invitations and having invited them into his traps, ${ }^{59}$ he himself is a wrongdoer and hence responsible. They met the wrongful trespass of the child with a temptation by the landowner, and made the tempter pay the bill. ${ }^{60}$ This was no small theological feat. It is employing one morality to defeat another as is involved in defeating contributory negligence by "wilful" negligence. ${ }^{61}$ But it was an unnecessary method of reaching a good result, ${ }^{62}$ except for the fact that the judges thought it necessary under their accepted theory. But the medieval domestic establishment with its yards and meadows, cultivated area and wild pasture, with its rock piles and fences, its brooks and decayed trees, is an entirely different sort of enterprise from that of a railway yard, a steam mill, a factory, a power system, a supply depot, an explosive storehouse, an abandoned plant, or many other such premises. It is different in drawing power for curious children, in the number and seriousness of the risks to which children are subjected, in the relative capacity of the landowner and parents to protect his premises from intrusion by means of fences, gates, guards, or otherwise, and it is different in that the costs of affording such protection can be cared for as part of the costs of the enterprise, and more than all, it is different in that the risk when it results in hurt to the child can best be borne and absorbed by this type of landowner. To these may be added the now accepted recognition that children are responsibilities of the community as a whole. Every consideration of economics, of ethics, of prevention, and of justice would all place a severe duty upon the landowner in such cases. And inasmuch as contributory negligence is seldom a factor in these cases, and the question of reasonableness is normally one for the jury, with the almost certain result that the defendant will be required to pay, the difficulties of administering these

\footnotetext{
${ }^{59}$ Keffe v Milwaukee \& St. P. Ry., 21 Minn. 207 (1875).

${ }^{80} \mathrm{It}$ is interesting to observe the seriousness with which the opponents of the doctrine argued against this point. See Smith's article, supra note 57; SELECTED ESSAYS ON THE LAW OF TORTS (1924) 360-368.

${ }^{61}$ Aiken v. Holyoke St. Ry., 184 Mass. 269, 68 N. E. 238 (1903) ; (1928) 17 CALIF. L. Rev. 65.

${ }^{82}$ Sioux City, etc., R. R. v. Stout, 17 Wall. 657 (U. S. 1873). In this leading case the court stated the doctrine with the utmost clarity. Defendant was negligent, plaintiff was too young to be contributorily negligent. The sinful plight of a trespasser upon land did not occur to the court. That was a ghost from the centuries past reincarnated in later cases. The court assumed the duty, i.e., that the negligence theory would apply to a landowner's use of his land as it does to the use of any other sort of property. Note also the good sense of Cooke v. Midland Great Western Ry., [1909] A.C. 229. The present method of rationalizing these cases is most inadequate. See United Zinc Co. v. Britt, 258 U. S. 268, 42 Sup. Ct. 299 (1921); Darsch v. Brown, 164 N. E. 177 (I11. 1928). Note the extreme position taken by one jurisdiction. Erie R. R. v. Hilt, 247 U. S. 97,38 Sup. Ct. 435 (1918).
} 
cases through the orthodox judicial process required for negligence cases would overwhelmingly demand that they be placed upon some basis of insurance similar to the workmen's compensation device. There is no rational basis to be found for continuing to handle the problems created by the industrialist landowner in the same manner as those created by the farmer and small tradesman. The assumption (stated in the decisions as a principle) which runs through hundreds of these cases that all landowners are to be subjected to the same responsibility is not necessary, nor is it well founded. There is no legal theory so flexible that its results will not be used against itself if it is made to care for such widely variant cases.

A somewhat similar development has taken place with reference to adults-those who walk on railway tracks or go upon the premises of industrial plants. Probably it is not startlingly immoral for persons to choose the smooth and dry roadbeds rather than the muddy streets of the outlying districts of large communities. Nor is it particularly sinful for people to satisfy their curiosities by entering and observing the operations of industrial plants. That these persons annoy and impose responsibilities upon the owner of such enterprises, even if only to keep intruders off the premises, is readily conceded. Nevertheless these curious intruders are found in increasing numbers invading these dangerous premises. And they are trespassers, or tolerated intruders at best, until a court invests them with the rights and privileges of licensees in order that the harshness of the earlier rules may be obviated. Many courts insist that railway operatives are under a duty to keep a lookout for such persons, that other landowners must warn or protect them from hidden dangers, and must refrain from negligent action while such persons are present. The costs cast upon industry to furnish this somewhat "bootleg" protection to unwelcome "guests" is after all not crushing. It is true that neither morals nor justice make a strong demand here in all cases. But the desirability of requiring the operators of the engines of traffic and the machines of industry to be highly regardful of human life, wherever it is encountered, and the ability of the owners and operatives to reduce the risks of hurt even as to those who insist upon subjecting themselves to such risks, is sufficient to warrant judgment for plaintiffs in many of these cases. The creative power of the courts to raise an intruder from the category of a trespasser to that of an invitee affords a basis for finding a duty in terms of negligence theory. The power of judges to work such miracles has always been beyond the understanding of those who would insist upon the sanctity of principles. But somewhow or other judges come to recognize the habits of their fellow beings as reflected in constantly re- 
curring tragic experiences, and to bend both principles and judgment to take them into account, long before the judges overcome their own habits of talking about such matters in the refined categories of "fault." Their judgments are years in advance of their language. Why continue to insist that there is no gulf between the thought and its expression? The judicial process does not require either the confusion or the bad habits resulting from carrying along these phrases which misrepresent everything that is being done. The normal negligence formula of "reasonable care under all the circumstances" was designed for just these cases in which judgment must have the widest range and in which uniformity, except in process, is impossible. The interests of the landowner would be protected under this formula equally as well as the interests of other persons, and he deserves nothing more. Both judge and jury have the same power under it as they have under the cumbersome categories used for classifying intruders, and much greater facility for exercising their power rationally. ${ }^{63}$

\section{Crossing Cases}

The "Stop, Look and Listen" alliteration of three generations ago is still taken seriously. Contributory negligence continues to be a vigorous defense in these cases. The rules as to crossings grew up when travel was both slight and slow, when railroads were daring economic ventures, and when pioneer morality not only insisted that every man look out for himself, but when a traveler had some assurance that by looking out for himself he could protect himself. Today railroads maintain multiple tracks. They have multiplied the number of trains they run and have increased their speed. The public highways

${ }^{\text {as }}$ There are many cases which fall into this group. The courts generally class the intruder as a trespasser or as a licensee or invitee as they desire to bless or damn him. Now and then a court deals with a case without resorting to these categories. See Southern Ry. v. Cochran, 29 F.(2d) 206 (C. C. A 5th, 1928); Lyman v. Hall, 219 N. W. 902 (Neb. 1928); McGlove v. Angus, 248 N.' Y. 197, 161 N. E. 469 (1928). But this is the exception. Norris v. Hugh N. C. Co., 206 Mass. 58, 91 N. E. 886 (1910); Castonguay v. Acme, etc., Co, 136 Atl. 702 (N. H. 1927); Moore v. Ohio Oil Co., 241 Ill. App. 388 (1926); Loney v. Lawrence Auto Co., 255 Pac. 350 (Wyo. 1927) ; Roper v. Commercial Fibre Co., 143 Atl. 741 (N. J. 1928) ; Pryotely v. N. Y., etc., Co., 28 F.(2d) 868 (C. C. A. 6th, 1928); Humphrey v. Twin State Gas \& Electric Co, 139 Atl. 440 (Vt. 1927); (1928) 12 Min. L. Rev. 420; Mallory v. Day Carpet \& Furniture Co., 245 I1l. App. 465 (1927); Teakle v. San Pedro, etc., R. R., 32 Utah 276, 90 Pac. 402 (1906); Palmer v. Oregon S. L. R. Co., 34 Utah 466, 98 Pac. 689 (1908); F. $\&$ M. Warehouse Co. v. Perry, 118 So. 406 (Ala. 1928) ; Anderson v. Androscoggin Pulp Co., 126 Me. 5, 135 Atl. 249 (1926) ; Kinsman v. Barton \& Co., 141 Wash. 311,251 Pac. 563 (1926); Douglas v. Bergland, 216 Mich. 380, 185 N. W. 819 (1921). Brigman v. Fiske-Carter Construction Co., 192 N. C. 791, 126 S. E. 125 (1926); Southern Ry. v. Matthews, 29 F.(2d) 52 (C. C. A. 6th, 1928); Terre Haute, etc., Co. v. Terrell, 164 N. E. 307 (Ind. App. 1928); Richardson v. Whittier, 164 N. E. 384 (Mass. 1929); Smith v. Twin State Gas \& Electric Co., 144 Atl. 57 (1928). See exhaustive comment, (1929) 77 U. OF PA. L. Rev. 506 . 
they intersect are crowded with fast moving traffic. In economic importance the gap between the highway and the railway has closed. The railway exercises a public franchise for private profit, while the highway is built and maintained at public cost for public use. The railway can protect the hordes of travellers by guards or passes at less cost and with more effect than travellers can protect themselves. The risks have increased both in number and in degree, but the railway has now grown rich. It is both able to protect against these risks and to distribute the loss when the protection fails. Every factor which determines judgment would seem to require that such risks should be eliminated altogether, but if any there should be, they should be placed upon the railway. The refined morals of negligence with its judge and jury process have no place here. Courts are constantly deciding these cases by harking back to a day when life was ordered on an entirely different scale and when a stiff morality assumed to hold a dominant place in the administration of law. Current legal theory at this point is wholly inadequate. The orthodox judicial process should be relieved of the bulk of this litigation. ${ }^{64}$

${ }^{64}$ As I write this note the newspapers report a crossing accident at Bellevue, Ohio, in which seventeen passengers of a bus were killed and others injured. Two years ago almost the entire football squad of Baylor University were killed in such an accident near Austin, Texas. Buses loaded with school children are not infrequently in such collisions. The toll of dead and injured mounts into the thousands annually.

The crossing problem was given great emphasis by the reversion to early type decision shown in Baltimore \& Ohio R. R. v. Goodman, 275 U. S. 66, 48 Sup. Ct. 24, 56 A. L. R. 645 (1927). See (1928) 16 Calif. L. Rev. 238; also extended Note (1926) 41 A. L. R. 405. The decision itself is very narrow, but even so, it points in the wrong direction. I understand that railroad companies posted and bulletined the opinion far and wide. Most jurisdictions fortunately have gone so far beyond the spirit of this case that they will not be greatly influenced by it. But judging from the numerous citations and discussions this decision has received it will probably work an over-cautiousness in many state courts and especially so in the federal courts The courts have never dallied quite so much with a serious problem which was at the same time so easy of solution. The following are only a few of the current cases: Greenwald v. B. \& O. R. R., 164 N. E. 142 (I11. 1928) ; Rosencranz v. Mich. Cent. R. R., 244 Mich. 147, 221 N. W. 273 (1928); Penna. R. R. v. Stegeman, 22 F. (2d) 69 (C. C. A. 6th, 1927); Jones v. Boston \& M. R. R., 139 Atl. 214 (N. H. 1927); Buck v. Rutland R. R., 143 Atl. 297 (Vt. 1928) ; Haskins v. Penna. R. R., 143 Atl. 192 (Pa. 1928); Grand Trunk Western Ry. v. Cathen, 163 N. E. 622 (Ind. App. 1928); Anvil v. Western Md. Ry., 19 F.(2d) 30 (C. C. A. 4th, 1927) ; Ill. Cent. R. R. v. Leichner, 19 F.(2d) 118 (C. C. A. 5th, 1927) ; Moreland v. Chicago \& N. W. Ry., 220 N. W. 692 (Neb. 1928); Germak v. Florida East Coast Ry., 117 So. 391 (Fla. 1928); Settich v. B. \& O. R. R., 29 F.(2d) 112 (C. C. A. 4th, 1928). When the legislature seeks to minimize contributory negligence the courts are sometimes so thoroughly indoctrinated with the "fault" theory that the legislation amounts to little. Gray v. Missouri Pac. Ry., 23 F.(2d) 190 (C. C. A. 6th, 1928). But see Tenn. Cent. R. R. v. Page, 282 S. W. 376 (Tenn. 1926); Southern Ry. v. Johnson, 143 S. W. 887 (Va. 1928).

Even though courts take a most liberal attitude towards persons injured at crossings, the negligence theory is wholly inadequate to cope with the situation. The situation demands such stringency as to eliminate the risk. Norfolk \& W. Ry. v. Holbrook, 27 F. (2d) 326 (C. C. A. 6th, 1928); Lawson v. Minneapolis, etc., Ry., 219 N. W. 554 (Minn. 1928). 


\section{Automobile Cases}

Probably the general traffic cases-pedestrian and motorist, motorist and motorist-furnish by far the largest number of cases of the current day. ${ }^{65}$ And doubtless also legal theory is here most out of joint. This is true despite the fact that insurance companies are constantly absorbing the overwhelming amount of these losses without suit, and in the face of the further fact that jury verdicts are little short of unanimity for the injured party. Ordinarily it is the most dubious case, either on negligence itself or on the legitimacy of the claim, that reaches the courthouse. The courts find themselves struggling hopelessly under this mass of cases. The licenses required for driver and car, speed laws, lights and brakes, rules of the road, traffic cautions and signals, together with an enormous increase of traffic officers do not appreciably cut down the number of injuries, the risks, or the work of the courts. As though there were no other way to do the job, the courts continue to inquire into the "fault" of the respective parties. ${ }^{66}$ In quantity of litigation, and also in the legal theories applicable to the particular case, traffic litigation is reaching totals far in excess of the enormous master-servant litigation of a generation ago.

But whatever the price, we have given over our ways to the motor vehicle, although the last one of us may become its victim. There can be no recessional. All the protective devices we shall design will not be enough. The "family purpose" 67 and "joint enterprise" 68 doctrines help

${ }^{65}$ Report of Calendar Committee, N. Y. L. J., June 23, 1927. See excellent article of Marx, Compulsory Compensation Insurance (1925) 25 ColumbIa Law REV. 164.

${ }^{80}$ The following are merely typical of the cases reported in the current reports: Woolmer v. Perry, 163 N. E. 750 (Mass. 1928) ; Johnson v. Boston \& M. R. R., 143 Atl. 516 (N. H. 1928) ; Cole v. Wilson, 143 Atl. 178 (Me. 1928); Brotman v. Doan, 143 Atl. 328 (N. J. 1928); Harber v. Graham, 143 Atl. 349 (N. J. 1928) ; Coombs v. Markley, 143 Atl. 261 (Me. 1928); Galvin v. Kreider, 143 Atl. 110 (Pa. 1928); Jacobson v. Parish, 4 S. W. (2d) 87 (Tex. Civ. App. 1927); Gaboury v. Tisdell, 158 N. E. 348 (Mass. 1927); Bowman v. Stoutman, 141 Atl. 41 (Pa. 1928); Village of Newburgh Heights v. Vanek, 163 N. E. 721 (Ohio Ct. App. 1928); Silver v. Silver, 143 Atl. 240 (Conn. 1928); Blands v. Kulesva, 141 Atl. 106 (Conn. 1928) ; Coca-Cola Bottling Co. v. Shipp, 299 S. W. 856 (Ark. 1927); Baker v. Hurwitch, 164 N. E. 87 (Mass. 1928). See five such cases reported from one sitting of the Supreme Court of Errors of Connecticut, 143 Atl. 881, 888 (1928).

${ }^{67}$ Goss v. Williams, 145 S. E. 169,172 (N. C. 1928). The following excerpt from the opinion indicates how much more good sense there is in talking in terms other than rules: "The question (family purpose doctrine) is for the first time presented to this court. The common law is elastic to meet the complex problems of the age as they arise, but courts should be slow and not enter the realm of legislation. Last year 22,160 people were killed in automobile accidents on the highways of the United States. In North Carolina, the last year, 571 were killed. During the first six months of this year 262 people in North Carolina were killed in automobile accidents, or an average of about $1 \mathrm{I} / 2$ a day, while an additional 2,088 were injured. The state total of motor cars on August 1, 
some but they do not go far. Too many people will continue to be hurt and subjected to serious risk without adequate protection. What court or group of laymen can so weigh faults as to pass with any precision upon the conduct of two swiftly moving automobiles, or two human beings equally bent on getting every second out of the day? And what difference does it make if they could? The motorist has chosen to make the streets unsafe. $\mathrm{He}$ is the one who gets the advantages from subjecting the pedestrian to perils. He can protect himself from financial hurt by a pittance, and as against the pedestrian at least, he runs little risk of suffering hurt either to his person or property. His ability to afford the advantages of a motor implies a like ability to supply protection against its hurts. In short, he imposes the risk, why should he not bear the loss when it comes? Justice is at her best here. And the case of motorist and motorist is little different. While justice is probably neutral as between these, the demands of a workaday world supply equally as severe exactions. The same economy is involved in compensating the hurt individual who either supports a family or is supported by some one who does as is involved in the employer-employee cases. Insurance is the best available protection we have against the inevitable. The hurts and injuries of a motorized society are largely of that type. Morality, economy, and justice would all require the person who creates hazards on a large scale to avail himself of the protection insurance gives in behalf of his victims. And of equal importance, the administration of these cases would require that the judges of orthodox courts be rid of this litigation by machinery of simpler design. No rational opinion would require courts with their delicately poised theories of negligence to stagger under these increasing burdens any longer than the

1928, was 440,258. Passenger cars numbered 396,295; trucks 43,963. State average, one motor car to every 6.6 inhabitants.

"Human life is too cheap and restraint is necessary. The numbers killed and crippled each year are appalling. It is necessary, in reason, for the courts to hold the owners of automobiles, when they turn over an instrumentality of this kind to the family for family use, to strict accountability. This is one of the means to safeguard the public. The head is usually the one of financial responsibility, at least he is the owner of the instrumentality. Upon the principles cited, consonant with natural justice, he should be held responsible."

Much faster headway with much less confusion would doubtless have resulted had the courts in earlier cases dealing with this problem faced it with more frankness instead of wasting so much time debating tenuous legal theories. See Lattin, Vicarious Liability and the Family Automobile (1928) 26 MICH. L. REv. 846; King v. Smythe, 140 Tenn. 217, 204 S. W. 296 (1918); In re Opinion of the Justices, 251 Mass. 569, 594, 147 N. E. 681, 693 (1925). But see Smith v. Callahan, 144 Atl. 46 (Del. 1929) for an opinion which insists upon the integrity of legal rules.

${ }^{68}$ See Note (1927) 48 A. L. R. 1078. 
time required to fashion legislation to care for them. ${ }^{69}$ In this class of negligence cases, as in those already discussed and others not discussed, it would seem that the duty problem has been determined so definitely and responsibility has been indicated so decisively through years of litigation, that nothing is left to be done which cannot be better performed by some less ponderous agency than an orthodox court. The expense item alone that comes from choking the judicial process with these cases is literally incalculable.

\section{Functions of the Judicial Process}

The judicial process in negligence cases is not greatly dissimilar from the judicial process in other cases. But negligence cases have afforded the process its greatest flexibility. It is extensive in these cases because of the machinery required in making use of a jury, and more so because negligence cases concern more largely the infinite variety of workaday contacts involved in the operation and development of the machines of industry and commerce. The judicial process in negligence cases is the experimental machinery of government-by-judges through which a restless and changing industrial society is furnished protection against its self-inflicted physical hurts. Only a few of the implications of such a conclusion can be stated here.

The most important, and the one most overlooked, is that "negligence" is a short term for a complex situation. There is some talk about a "tort of negligence." This can only be intended in a catchword sense. Government furnishes for use in the infinite variety of cases classed as "negligent," (and that only after the hurt has been received), a process consisting of judge and jury, plus "ready to wear" formulas for ascertaining the judgment of judge and jury, as a means of ad-

${ }^{69} \mathrm{~S} \rightarrow$ Elsbree and Roberts, Compulsory Insurance Against Motor Vehicle Accidents (1928) 76 U. of PA. L. REv. 690; Lohman, Compulsory Automobile Insurance (1927) 130 The Annals of the Am. Academy of Pol. \& Social ScI. 163.

The following is an excerpt taken from a New York Times report (Sunday, Jan. 27, 1929) of a speech made by A. B. Barker, manager, transportation department, Chamber of Commerce of the United States:

For these three groups of percentages of increases in automobile fatalities between 1920 and 1927 are:

North Atlantic States (Maine to Maryland, inclusive) :

Increase in automobile registrations $\ldots \ldots \ldots \ldots \ldots \ldots \ldots \ldots \ldots$

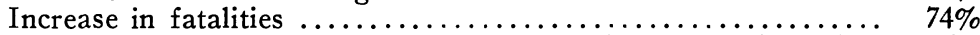

Middle Western States (Ohio, Indiana, Illinois, Michigan, Wisconsin, Minnesota, Missouri, Kansas and Nebraska) :

Increase in automobile registrations $\ldots \ldots \ldots \ldots \ldots \ldots \ldots \ldots \ldots \ldots$

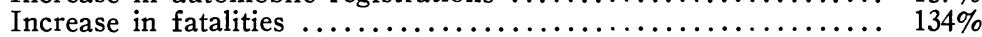

Southern States (Virginia, North and South Carolina, Kentucky, Tennessee, Mississippi and Louisiana):

Increase in automobile registrations $\ldots \ldots \ldots \ldots \ldots \ldots \ldots \ldots \ldots \ldots$

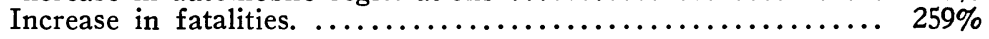


justing the loss. Another way of saying the same thing is that judge and jury with their paraphernalia are furnished as a means for determining the defendant's responsibility and assessing the damages. I have already outlined somewhat how the process works. Its first step involves a determination of "duties" by the judge-an alteration of some general formula to fit the particular case-and it is about this phase of the process that legal theories are thickest. Judges have stated many rules in an attempt to make the determination of "duties" easier.

In the course of any period of economic activity during which litigation increases greatly, current legal rules and theories reach the breaking point at many places. The requirements of business, ethical standards, the available safeguards, the relative capacity of parties to bear the risk involved, the exigencies of administration, or one or more of these factors, invariably changes. Thus the rules and theories which courts devise at one stage fall out of joint at succeeding stages. It is a habit of long standing to think of the rules and theories developed by courts as involving "principles" to which adherence must be given at all costs. Human nature is so constituted that it normally insists on standing by its "principles." Here are found serious difficulties of readjustment and realignment. As a matter of fact, so far as rules of law are concerned these "principles" are nothing more than the generalizations (assumptions) drawn from the factors which determined the initial judgment; the hypotheses upon which a theory of responsibility was based. And these factors having changed, the initial judgment should no longer stand. "Principles" should therefore be expected to vary as do the factors which support them, but as a matter of fact they lag far behind. Usually they are never again in alignment after the first judgment.

In contrast, the other parts of the judicial process-the judge and jury - newly set up with each new case, permit the widest latitude in passing judgment with reference to the factors which at any particular time and place may then appear to be relevant. Too little attention has been paid to these parts of the process. They are of greater importance than rules and formulas, and no statement of rules made without reference to the purpose they are to perform can be of any value. In fact it has been assumed that these variables (judge and jury) could and should also be stabilized by rules and formulas. It is thus that such tremendous emphasis has come to be placed on rules and formulas as stabilizing factors. But it ought to be obvious that a process designed for adaptability cannot and should not, either in operation or in results, be subjected to any high standardization. And here lies the chief mistake of those who have worked so assiduously to standardize the "law 
of negligence." The process in negligence cases, of all the patterns of the judicial process, is least fixed and most flexible. Judge, jury, and formulas which go to make up the process may react differently in every case. The process is highly individualistic, highly elastic. It allows the widest latitude for judgment. No aggregate of scholars or judges or practitioners can anticipate its judgment with assurance in a single complex case. Each case is new to it and must be subjected to it for a fresh judgment. It is slow and tedious. It is not designed to carry the heavy burdens of the types of cases for which responsibility has been developed through it. It only operates efficiently so long as a solution is being pondered. When society has made up its mind and insists upon quantity production-something automatic and uniform, something simple and "fool proof"-the high individualism of the judicial process in negligence cases will prevent its meeting these demands. Here the stage of experiment has passed and a standardized machinery which gives dependable results without exacting too much judgment is required. This is the stage for highly specialized courts, ${ }^{\mathbf{7 0}}$ for workmen's compensation, inspection, licenses, commissions and other so-called administrative devices. The slowness with which intelligent opinion accepts these instrumentalities can only be understood by recalling how bitterly at every step the hand and muscle workers generally have fought the advent of labor saving machinery. It is widely assumed that these administrative agencies are in some way set up in opposition to the courts, and thus they have frequently drawn the fire of the courts themselves. As a matter of fact they are designed to relieve the courts of work that they should not be expected to do, are not equipped to do, and are not needed to do. It is enough for the courts to keep these agencies acting within reasonable bounds. As a matter of fact a workmen's compensation or similar board is much like a specialized jury, but one that does not require the close watch and superintendence required by a common law jury. As here suggested, such an agency would be a specialized assessor of damages. The courts would continue to exercise the power of supervision as to important questions which still should be subjected to the judicial process for solution, but would be relieved of the mass of minutiae which so quickly clog the judicial process and prevent it from performing the important functions for which it was set up.

${ }^{70}$ The traffic courts in most cities are not much more than collection agencies. The penalities imposed are highly uniform, and it is only the most exceptional case that is subjected to the judicial process in the sense of trial. The same tendency is marked in the courts of congested centers with reference to the prohibition cases. The handling of uncontested divorce cases is of the same character. It must be, when a single judge, as one Houston, Texas, judge did, may grant in excess of 200 divorces in a single day. Even the more conservative Connecticut courts denied divorces in only 28 out of 1554 such cases during a two-year period. There are other similar classes of cases. See Clark, Fact Research in Law Administration (1928) 2 ConN. BAR J. 211. 
But it is not always necessary that courts await legislation to relieve them of the glut of cases which their own process has brought upon them. Judges may gauge their power within limits from the most drastic to the other extreme. They have often reduced litigation to the vanishing point. Rules and formulas and doctrines are seldom designed as controls of judicial behavior, but are the means for judges to employ in their control of the conduct of others. That judges are controlled somewhat by the rules, formulas and doctrines which they use is of course as inevitable as that any one is influenced by his environment. But judges are expected, as are other persons, to be able to maintain a fair domination of their surroundings, and in the main they do so. Judges were not helpless in reducing to a simple basis the responsibility of the keeper of wild animals for the hurts done by them. The protection of property from the invasion of domestic animals was likewise made decisive. Courts of the western and southern states completely reversed the common law theory requiring the owners of cattle to fence them in. The extreme use of power in Rylands $v$. Fletcher was not as misguided as sometimes thought. ${ }^{71}$ The practical elimination of the

${ }^{71}$ See Green v. General Pet. Corp., 270 Pac. 952 (Cal. 1928) in which an oil company was held responsible to adjacent land owner for damages done to his property by blowing out of oil well which was being drilled with all due care. It is most misleading to think of these cases as accurately described by the catchphrase "absolute liability." The attitude of the California court is a good example. It had repudiated this "doctrine" in the dam cases. Sutliff v. Sweetwater Water Co., 182 Cal. 34, 186 Pac. 766 (1920). See Green v. General Petroleum Corp., 262 Pac. 377 (Cal. 1928). The economic factors were aligned differently in California in 1920 than they were in England in 1860. But when the Green case came along, the court properly ignored the commitment it had made doctrinally and decided the case on a broader basis. The dangers of doctrines are not always so easily escaped. The attempt made by the court to keep its legal theory intact and its resort to the "sic utere," etc., maxim, are most interesting. A somewhat similar situation is involved where both the railroad and farmer have permitted the right of way and farm respectively to grow up in grass. Sparks from a well-equipped and operated engine set fire to the grass on the right-of-way and the farmer's property is burned. See Kellogg v. Railway, 26 Wis. 233 (1870) ; cases cited in Bohlen, CAses on TorTs (2d ed. 1925) 506. The courts say "the doctrine of contributory negligence is entirely out of place here." Leroy Fibre Co. v. Chicago, etc., Ry., 232 U. S. 340,34 Sup. Ct. 415 (1914). But why so? Do not the courts mean that the economic and justice factors are so strong in these cases that there is no place for matching moralities (faults)? Does this mean that the same conclusions must be reached in such cases at other times and under other conditions? Would the same rule be applied between farmers owning adjacent farms?

A gasoline filling station may be a nuisance in every sense of that word except in the court's judgment. It may reduce the value of adjoining property, create fire hazards, turn a quiet corner into a noisy one to the aggravation of the whole neighborhood, increase the dangers from traffic to the neighborhood children, but to a world which uses automobiles, filling stations are indispensable. Brown v. Easterling, 110 Neb. 729, 194 N. W. 798 (1923); Powell v. Craig, 113 Ohio St. 245, 148 N'. E. 607 (1925); Hanes v. Carolina Cadillac Co., 176 N. C. 360, 97 S. E. 162 (1918); cf. Carney v. Pa. Oil Co., 140 Atl. 133 (Pa. 1928). Pure business practicalities have the right-of-way in many such groups of cases.

The same sort of problem is inevitable in determining the aviator's liability.

See Lee, Law Memoranda upon Civil Aeronautics (U. S. Printing Office 1928) 89 et seq. 
passenger-railway damage suit was a result of equally severe use of power. ${ }^{72}$ The negligence per se device in cases involving violations of police regulations tends in the same direction and would be efficacious were it not too drastic for many cases, and were it not possible under the doctrine of contributory negligence and proximate cause to use it just as effectively to defeat the very purpose for which it is designed. Slander per se and libel per se save many extended inquiries. The "innocent misrepresentation" doctrine when fully matured will do even more in facilitating the administration of deceit cases. ${ }^{\mathbf{7 3}}$ There are other instances doubtless more significant. Whenever judges have felt that the stage of experimenting was past and certain adjustments to be desirable, they have seldom hesitated to employ their power to such ends. That is what they should do. Probably after all, a vocabulary of absorbent phrases which defy rational analysis enables them to exercise this power all the more frictionlessly. But I disclaim for them any purposeful vagueness. I rather believe that most judges feel themselves bound by what they choose to think a technic of long development, and they feel they must be able to translate the factors which are here sought to be identified into such technic before they can conscientiously consider them in passing judgment. They are thus not infrequently impelled to surrender their power of passing judgment to what appear to be the exigencies of their legal theory. That there are other judges who have expanded the bonds of any such technic is equally certain. Their habit of dragging the factors which control judgment out into the open beyond the reach of unnecessary language paraphernalia is one to be encouraged. ${ }^{74}$ Nothing, on the one hand, will so promote a legal science as the recognition of the limitations of language as a control of judgment. And on the other hand, there is no instrumentality so necessary in making judgment effective as highly adaptable words. But these words do not have to be "canonized." "Rights" and "duties," "wrongs" and "faults" and their kindred must surrender their sanctity;

\footnotetext{
${ }^{72}$ See supra note 3.

${ }^{73}$ See Miller, Innocent Misrepresentation as the Basis of an Action for Deceit (1928) 6 TEX. L. Rev. 151; Comment (1928) 37 Yale L. J. 1141.

${ }_{74}$ The clear expression of Cardozo, C. J., in Hesse v. Rath, 249 N. Y. 435 164 N. E. 342 (1928), holding that the acquisition of an airport is a public and municipal purpose is a good example: "Aviation is today an established method of transportation. The future, even the near future, will make it still more general. The city that is without the foresight to build the ports for the new traffic may soon be left behind in the race of competition. Chalcedon was called the city of the blind, because its founders rejected the nobler site of Byzantium lying at their feet. The need for vision of the future in the governance of cities has not lessened with the years. The dweller within the gates, even more than the stranger from afar, will pay the price of blindness." The celebrated case of Slover v. Ransom by the same court, 224 N. Y. 233, 120 N. E. 639 (1918), is of the same sort. See also the remarks of Chief Justice Taft in Weil v. Neary, 49 Sup. Ct. 144, 149 (U. S. 1928).
} 
scientific government is opposed. They are not to be trusted with power beyond that of conveying thought. We need less "authoritativeness" than we think. Judgment in the particular case, based upon all the factors which may be relevant at the time and place, as unobstructed and as clear as it can be given, is the immediate function of the multiple coiled judicial process. There is no assurance in such a formula save as it may be grasped by the intelligence of those to whom the power to pass judgment is entrusted. But government hangs here.

LEON GREEN

YaLe Law School 